\title{
ADD3 wt Allele
}

National Cancer Institute

\section{Source}

National Cancer Institute. ADD3 wt Allele. NCI Thesaurus. Code C80079.

Human ADD3 wild-type allele is located within 10q24.2-q24.3 and is approximately $130 \mathrm{~kb}$ in length. This allele, which encodes gamma-adducin protein, is involved in the modulation of actin-spectrin network assembly. Genetic variation may be associated with the relapse of acute lymphoblastic leukemia. 